\title{
Girart de Vienne, Traduction en français moderne par Bernard Guidot
}

\section{G. Matteo Roccati}

\section{(2) OpenEdition}

10 Journals

\section{Édition électronique}

URL : http://journals.openedition.org/studifrancesi/6177

DOI : 10.4000/studifrancesi.6177

ISSN : 2421-5856

Éditeur

Rosenberg \& Sellier

\section{Édition imprimée}

Date de publication : 1 novembre 2010

Pagination : 524

ISSN : 0039-2944

\section{Référence électronique}

G. Matteo Roccati, «Girart de Vienne, Traduction en français moderne par Bernard Guidot», Studi

Francesi [En ligne], 162 (LIV | III) | 2010, mis en ligne le 30 novembre 2015, consulté le 08 janvier 2021. URL : http://journals.openedition.org/studifrancesi/6177 ; DOI : https://doi.org/10.4000/studifrancesi. 6177

Ce document a été généré automatiquement le 8 janvier 2021.

\section{(c)}

Studi Francesi è distribuita con Licenza Creative Commons Attribuzione - Non commerciale - Non opere derivate 4.0 Internazionale. 


\title{
Girart de Vienne, Traduction en français moderne par Bernard Guidot
}

\author{
G. Matteo Roccati
}

\section{RÉFÉRENCE}

Girart de Vienne, Traduction en français moderne par Bernard GUIDOT, Paris, Honoré Champion Editeur, 2006 («Traductions des classiques français du Moyen Âge», 74), pp. XLVI-262.

1 L'introduction présente les principaux thèmes de la chanson ainsi que les procédés littéraires mis en œuvre. La traduction, en prose, est suivie des notes (pp. 209-237), de la bibliographie et de l'index des noms propres. 